\title{
Effects of processing methods on nutritional composition of improved soybean varieties for soymilk production
}

\author{
Demelash Hailu Mitiku* \\ Department of Food Science and Postharvest Technology, Jimma University, Jimma, \\ Ethiopia
}

\begin{abstract}
Value addition efforts in respect of using soybean in various food applications are scarce in Ethiopia. The effect of processing methods was investigated on nutritional composition of improved soybean varieties for soymilk production. The experiment was carried out in a factorial design, improved soybean variety as the first factor (Didessa, Katta and Korme) and processing methods as a second factor of three levels (Illinois, Cornel and Traditional method), replicated three times. The Cornel processing method gave the highest ash content $(0.32 \%)$ from Korme and the lowest $(0.27 \%)$ from Didessa and Katta varieties. The highest $(2.60 \%)$ crude protein content was recorded from Didessa and the lowest $(2.13 \%)$ from Katta, using Cornel processing methods. The highest carbohydrate content $(13.21 \%)$ was recorded from Didessa and the lowest $(6.87 \%)$ from Korme. The highest $(75.93 \mathrm{kcal} / 100 \mathrm{~g})$ energy content was recorded from Didessa and the lowest $(51.77 \mathrm{kcal} / 100 \mathrm{~g})$ from Korme, by Cornell processing method. Generally, Cornel processing method was the best of the three processing methods for improved variety of soybean. From the three varieties of improved soybean, Didessa had higher nutritional composition and could be used in different food product development efforts and can contribute in addressing the food security problems of Ethiopia.
\end{abstract}

Keywords: Improved variety; Processing methods; Soymilk; Nutritional composition; Minerals.

DOI: https://dx.doi.org/10.4314/ejst.v14i2.4

\section{INTRODUCTION}

Soybean (Glycine max L. Merrill) belongs to family Fabaceae. It is native to China and is one of the oldest world crops. It is widely grown in tropical and temperate regions of the world (Onuorah et al., 2007). The cultivation of

\footnotetext{
* Corresponding author: hailudeme@gmail.com

(C)This is an Open Access article distributed under the terms of the Creative Commons Attribution License (http://creativecommons.org/licenses/CC BY4.0)
} 
soybean in Ethiopia dates back to the 1950s (Shurtleff and Aoyagi, 2009). To date, the main attention of many research initiatives was to develop varieties that are high yielding, early maturing and tolerant to disease and drought (EARO, 2001). Soybean has been used in different food applications in the recipe of some infant foods in Ethiopia. One of the evidences could be efforts made by the Faffa Company in Ethiopia which has been working on the production of different soy products as a soy-fortified complementary food since 2003 and has become the first in the country to produce powdered soymilk (Eskedar Kifle, 2012).

In addition to other food products, soybean is known to be among the major legumes that have been used in vegetable milk production. In line with this, efforts were made to use soybean in the processing of soymilk at small-scale farming level by women entrepreneurs in Ethiopia under the support of agricultural research centers. These efforts were aimed at enhancing the use of soybean in the daily food of the households. Soymilk is used as vegetable alternatives to dairy milk in the formulation of infant foods because they have high protein, minerals and vitamins (Tunde-Akintunde and Souly, 2009; Aidoo et al., 2010; Odu et al., 2012).

Soymilk resembles cow's milk in appearance and it is nutritionally comparable with the human and cow's milk and hence can be comfortably used in place of cow's milk in some recipes (Khode et al., 2015; Ugochi and Chukwuma, 2015). Soymilk is cholesterol-, gluten- and lactose-free, while containing phytochemicals (Nezif Abachebsa et al., 2016). Therefore, it is considered as important healthy drink for people who are allergic to cow's milk proteins or have lactose intolerance and those who have special health or religious diet requirements (Murtaza and Shahid, 2007; Rehman et al., 2007; $\mathrm{Xu}$ and Chang, 2009; Bansal and Kaur, 2014; Adebayo-Tayo et al., 2009). Soymilk is also a rich source of soluble and insoluble dietary fibers, and isoflavones whose presence in everyday diet is very important (Obadina et al., 2013).

On the other hand, extensive consumption of soymilk is constrained by a number of factors related to the inherent constituents of soybeans including "beany" taste causing compounds and antinutritional factors that can reduce nutrient bioavailability (Nezif Abachebsa et al., 2016). The main factor which hampers utilization of soymilk is the "beany flavor" that results from lipoxygenase-catalyzed reaction of polyunsaturated lipids especially linoleic acid producing products such as aldehydes, ketones and alcohols (Rehman et al., 2007). These oxidation products are the main causes of undesirable objectionable flavor of soymilk and they are major hindrances on the 
acceptability of soymilk (Rehman et al., 2007; Kale et al., 2012). Other important demerits to the acceptability of soymilk are the astringency (throat catching factor) of soymilk which is related with flavor sensation. This sensation results from the interaction of polyphenolic substances present in soymilk with mucoprotiens in the mouth and throat (Rehman et al., 2007). Different methods have been used to overcome the problem of off-flavor in soymilk using herbal additives in different parts of the world including Ethiopia. Proper processing of soybean into soymilk is important to suppress undesirable properties (off-flavor due to the activity of lipoxygenase enzymes with unsaturated fatty acids in soybean) and anti-nutritional factors such as trypsin inhibitors which will hinder nutrient digestibility and absorption (Tunde-Akintunde and Akintunde, 2002; Obadina et al., 2013). However, in some conditions thermal processing detrimentally affects nutritional and quality attributes of soymilk and produces strong off-flavors (Lozano et al., 2007).

Blanching and soaking of the beans in water are among the remedial actions to overcome the negative effect of inherent components of soybean (Rehman et al., 2007; Odu et al., 2012; Obadina et al., 2013). Despite the potential of soybean for improving food and nutrition security, and its importance for income generation through sale and employment opportunities in soymilk processing sectors, little information is available in the literature about the types of soybean varieties and processing methods that can produce soymilk with superior nutritional quality. Moreover, soymilk processing and consumption in Ethiopia is not common. Processing at cottage or industrial scale is uncommon in Ethiopia. With this gap of information, this study was conducted to evaluate the effect of soybean varieties and processing methods on nutritional composition and mineral contents of soymilk. The study was, therefore, undertaken to investigate effects of different processing methods on nutritional composition of improved soybean varieties Didessa, Katta and Korme for soymilk production.

\section{MATERIALS AND METHODS}

\section{Sample collection and preparation}

Three soybean varieties (Didessa, Katta and Korme) grown under similar agronomic practices and management conditions were obtained from Bako Agricultural Research Center, Bako, Ethiopia. The soybean samples were sown and harvested at the same time during 2008/2009. These varieties were 
selected because of their adaptability to a wide range of agro-ecological locations in the country and their greater importance (MoARD, 2009). About $20 \mathrm{~kg}$ of each variety of soybeans was kept in a bag and transported to Wollega University (Shambu Campus), Ethiopia. It was then stored in the Food Science and Nutrition laboratory at room temperature until further processing. Some laboratory analyses were carried out in the Postharvest Technology laboratory, Jimma University, Ethiopia.

\section{Experimental design}

The experiment was carried out in $3 \times 3$ factorial arrangement with three soybean varieties and three processing methods in a completely randomized design (CRD) with three replications. The three soybean varieties were (Didessa, Katta and Korme). The statistical model employed is presented below:

$$
\mathrm{Y}_{\mathrm{ijk}}=\mu+\mathrm{t}_{\mathrm{i}}+\mathrm{b}_{\mathrm{j}}+(\mathrm{tb})_{\mathrm{ij}}+\mathrm{e}_{\mathrm{ijk}}
$$

Where $\mathrm{Y}_{\mathrm{ijk}}=$ the overall observations; $\mu$ = overall means; $t_{i}=$ is the effect of $i$ th variety $(i=1,2,3) ; b_{\mathrm{j}}=$ the effect of the $j$ th processing method $(j=1,2$, $3) ;(\mathrm{tb})_{\mathrm{ij}}=$ the interaction effect of the $i$ th variety using $j$ th processing methods; $\mathrm{e}_{\mathrm{ijk}}=$ the error term.

\section{Preparation of soymilk}

Three different methods described by Johnson and Snyder (1978) were used in soymilk production. The methods include Illinois, Cornel and Traditional. Soymilk samples were produced from each of variety following the three different methods as detailed below. For each method, $200 \mathrm{~g}$ of soybean was used. For the Cornel and Traditional methods, the sample soybean seeds were soaked in two liters of water while for the Illinois process, samples were soaked in 2 litres of $0.5 \% \mathrm{NaHCO}_{3}$. All the samples were soaked for $28 \mathrm{~h}$ and then decoated and rinsed with tap water.

\section{Illinois method}

The three soybean seed varieties were screened and soaked in $0.5 \% \mathrm{NaHCO}_{3}$ solution for $28 \mathrm{~h}$, then drained, decoated manually and rinsed with tap water. Then the soybean was blanched at $100{ }^{\circ} \mathrm{C}$ in $0.5 \% \mathrm{NaHCO}_{3}$ solution for 30 min and ground at 27 to $30{ }^{\circ} \mathrm{C}$ using soymilk making machine (SC20COMM Pristine Plant, India). Then it was sieved with $0.04 \mathrm{~mm}$ sieve and pasteurized at $68{ }^{\circ} \mathrm{C}$ for $30 \mathrm{~min}$ and soymilk was obtained. 


\section{Cornel method}

The three soybean seed varieties were screened and soaked in tap water for 28 h. Then, they were drained and rinsed in hot water at $100{ }^{\circ} \mathrm{C}$ for $20 \mathrm{~s}$. Then they were ground using soymilk making machine (SC20COMM Pristine Plant, India) with boiling water and sieved with $0.04 \mathrm{~mm}$ sieve, and finally pasteurized at $68{ }^{\circ} \mathrm{C}$ for 30 minutes and soymilk was obtained for further analysis.

\section{Traditional method}

The three soybean seed varieties were screened and soaked in tap water for 28 $\mathrm{h}$. Then, the water was drained and the soybean seeds were decoated manually and rinsed twice with tap water. The seeds were ground at 27 to $30{ }^{\circ} \mathrm{C}$ using soymilk making machine (SC20COMM Pristine Plant, India) and sieved with $0.04 \mathrm{~mm}$ sieve. Finally, the extracted soymilk was pasteurized at $68{ }^{\circ} \mathrm{C}$ for 30 minutes and kept for further analysis.

\section{Data collection}

\section{Determination of proximate composition}

The chemical composition of the soymilk produced with different processing methods including moisture, crude fat, crude protein, crude fiber and total ash were determined using AOAC official methods of 925.09, 4.5.01, 979.09 and 923.03, respectively (AOAC, 2000). Total carbohydrate was determined by difference as $100-(\%$ Moisture $+\%$ crude protein $+\%$ Crude fat $+\%$ Crude fiber $+\%$ Ash) (Wangcharoen, 2008). Results were expressed as $\mathrm{g} / 100 \mathrm{~g}$ of dry matter. Energy values were calculated using Atwater's conversion factors, where carbohydrates and proteins gave $4 \mathrm{kcal} / \mathrm{g}$ while lipids gave $9 \mathrm{kcal} / \mathrm{g}$ (Wangcharoen, 2008).

\section{Determination of minerals}

\section{Phosphorus content}

Phosphorus contents were determined after dry ashing followed by digestion of $1 \mathrm{mg}$ of freeze-dried soymilk powder by measuring the absorbance of the blue color of phosphomolybdate at $822 \mathrm{~nm}$ with UV-vis spectrophotometer (T80 UV/VIS Spectrophotometer) (AACC, 2000) method 40-56.01. Phosphorous contents were estimated from a series standard $(0.2-10 \mu \mathrm{g} \mathrm{P} / \mathrm{ml})$ calibration curve prepared from K2HPO4. 


\section{Iron content}

Iron (mg/100 $\mathrm{g}$ sample) were determined after dry-ashing followed by digestion of $2.0 \mathrm{~g}$ of freeze-dried soymilk powder by measuring the absorbance of $\mathrm{Fe}^{+2}-1,10$-phenanthrolinered complex color at $248.4 \mathrm{~nm}$ using atomic absorption spectrophotometer (Varian, SpectrAA20 plus, Toyama, Japan). Iron content was estimated from a calibration curve $(0.5-4 \mathrm{mg} \mathrm{Fe} / \mathrm{mL})$ prepared from analytical $\mathrm{Fe}\left(\mathrm{NO}_{3}\right)_{2}$. Samples were diluted with deionized water on an air-acetylene flame (model 6, Denmark) as a source of energy for atomization prior to introduction to AAS (AACC, 2000).

\section{Zinc content}

Zinc (mg/100 g sample) was determined after digestion of about $2.0 \mathrm{~g}$ freezedried soymilk powder by Atomic Absorption Spectrophotometer (AAS) at $213.9 \mathrm{~nm}$ using air-acetylene as source of energy for atomization (AACC 2000). Zinc level was estimated from a standard calibration curve $(0.25-2 \mathrm{mg}$ $\mathrm{Zn} / \mathrm{mL}$ ) prepared from analytical grade $\mathrm{Zn}\left(\mathrm{NO}_{3}\right)_{2}$. The methods were validated by simultaneous analysis of the standard reference material (Soya Bean Flour, INCT-SBF-4), with accuracy for Fe and Zn of 96.7 and 94.2\%, respectively. Finally, the mineral contents in soymilk samples were expressed in $\mathrm{mg} / 100 \mathrm{~g}$ of dry mass.

\section{Calcium}

The calcium content was determined following the oxalate precipitation method as described by Kirk and Sawyer (1991). The amount of was calculated using the following formula:

$$
\text { Calcium }(\mathrm{mg})=\frac{2 \mathrm{~V}}{W}
$$

Where $\mathrm{V}=$ volume $(\mathrm{mL})$ of standard $\mathrm{KMnO}_{4}$ solution required to titrate calcium oxalate; $\mathrm{W}=$ Weight $(\mathrm{mg})$ of soymilk sample taken to prepare ash.

\section{Statistical analysis}

All the data collected were subjected to analysis of the variance (ANOVA) using SAS 9.1 software package (SAS Institute Inc., Cary, NC). The differences between means were compared using Fisher's least significant difference (LSD) at a significance level of 5\%. 


\section{RESULTS AND DISCUSSION}

\section{Effects of soybean processing on proximate composition of soymilk}

\section{Cornel method}

The moisture content of soymilk produced from different varieties of soybean ranged from $82.3 \%$ to $88.6 \%$ for Didessa and Korme variety, respectively (Table 1). There was significant difference $(P<0.05)$ between the three soybean varieties. The highest value of the moisture content which ranged from 82.3 to $88.6 \%$ corresponded with that of Enwere (1998) who reported $92.8 \%$ of soymilk was water. The protein composition ranged from 2.13 of Didessa variety to $2.60 \%$ of Katta variety. Varieties significantly varied in protein content $(P<0.05)$. Similar works reported by Khatib et al. (2002) on which the protein content ranged from 2.8 to $4.1 \%$. The values of protein content obtained were lower than the values reported by Afroz et al. (2016) in which they found the values between 34.83 to $38.75 \%$.

The highest fat composition was found from Korme (1.64\%) and the lowest from Didessa $(1.41 \%)$. There was no significant difference $(P>0.05)$ in fat content between Didessa and Katta varieties. Korme was significantly different $(P<0.05)$ compared to the two varieties (Didessa and Katta). These figures obtained were comparable to those obtained by Babajide (1985) who stated that soymilk contained $2.12 \%$ fat. The value of the fat content was lower than the value reported by Suruga et al. (2007) (20.0\%) and Rashad et al. (2011) (12.0\%). But it was higher than the value of $0.8 \%$ reported by Muroyama et al. (2006).

Table 1. Effects of soybean processing on proximate composition (Cornel method).

\begin{tabular}{|c|c|c|c|c|c|}
\hline \multirow{2}{*}{ Parameters } & \multicolumn{3}{|c|}{ Variety } & \multirow{2}{*}{\multicolumn{2}{|c|}{ CV SD }} \\
\hline & Didessa & Katta & Korme & & \\
\hline Moisture (\%) & $82.33 \pm 0.06 \mathrm{c}$ & $86.43 \pm 0.02 b$ & $88.64 \pm 0.02 \mathrm{a}$ & 0.09 & 0.15 \\
\hline Protein $(\%)$ & $2.60 \pm 0.01 \mathrm{a}$ & $2.13 \pm 0.01 \mathrm{c}$ & $2.39 \pm 0.01 \mathrm{~b}$ & 0.58 & 0.03 \\
\hline Fat $(\%)$ & $1.41 \pm 0.01 \mathrm{~b}$ & $1.43 \pm 0.01 b$ & $1.64 \pm 0.01 \mathrm{a}$ & 0.92 & 0.03 \\
\hline Ash (\%) & $0.27 \pm 0.01 \mathrm{~b}$ & $0.27 \pm 0.01 \mathrm{~b}$ & $0.32 \pm 0.01 \mathrm{a}$ & 5.31 & 0.03 \\
\hline Fiber $(\%)$ & $0.18 \pm 0.01 \mathrm{a}$ & $0.14 \pm 0.01 \mathrm{~b}$ & $0.14 \pm 0.01 b$ & 6.52 & 0.02 \\
\hline Carbohydrate (\%) & $13.21 \pm 0.06 \mathrm{a}$ & $9.59 \pm 0.03 b$ & $6.87 \pm 0.01 \mathrm{c}$ & 0.69 & 0.14 \\
\hline Energy (kcal/100 g) & $75.93 \pm 0.22 \mathrm{a}$ & $59.78 \pm 0.08 \mathrm{~b}$ & $51.77 \pm 0.12 \mathrm{c}$ & 0.42 & 0.53 \\
\hline
\end{tabular}

ins within a row with the same letter(s) are not significantly different from each other at $\alpha=0.05$; CV

$=$ Coefficient of Variation, LSD $=$ Least Significance Difference. 
The values of crude fiber content ranged from 0.14 to $0.18 \%$. There was no significant difference $(P>0.05)$ between Katta and Korme, while there was significant difference $(P<0.05)$ between Korme and the other two varieties. This is in line with the work of Enwere (1998) who reported that soymilk contains no crude fiber or if it occurs it is very small, because of the processing, variety difference (structure) of the soybean and the soil profile. But it was lower than the value (9.2\%) reported by Zhu et al. (2008) and Fafaungwithayakul et al. (2011) with their value (3.52\%).

The values of the ash contents ranged from $0.27 \%$ for Didessa to $0.32 \%$ for Korme and there was no significant difference $(P>0.05)$ between Didessa and Katta varieties, but there was significant different between Korme and the others. This value is lower than the value reported by Afroz et al. (2016) on their work of preparation of soymilk using different methods and they reported the value of 5.10 to $6.54 \%$. This is in line with the work of Nezif Abachebsa et al. (2016) in which they reported the value $(0.26$ to $0.57 \%)$ on soymilk from different varieties of soybean.

Carbohydrate content ranged from 6.9 from Korme to $13.2 \%$ from Didessa. The carbohydrate contents were significantly different $(P<0.05)$ among the varieties. The current carbohydrate content was higher as compared to $2.6 \%$ of Redondo-Cuenca et al. (2010) and 3.8 to $5.3 \%$ of Van der Riet et al. (1989). But it was lower than the value of Hsieh and Yang (2004) on their carbohydrate content with value of $52.6 \%$ and $53.6 \%$, respectively. The energy content was higher $(75.93 \mathrm{kcal} / 100 \mathrm{~g})$ from Didessa variety and lower from Korme variety $(51.77 \mathrm{kcal} / 100 \mathrm{~g})$, which was significant $(P<0.05)$. USDA nutrient database reports showed $446 \mathrm{kcal} / 100 \mathrm{~g}$.

The mineral composition of soymilk from different varieties of soybean is shown in Table 2. The phosphorous content ranged from 84.6 to 85.82 $\mathrm{mg} / 100 \mathrm{~g}$ in which the highest value was recorded from Korme variety and the lowest, i.e., $84.6 \mathrm{~g} / 100 \mathrm{~g}$, from Didessa variety. Varieties significantly varied in mineral composition $(P<0.05)$. Nezif Abachebsa et al. (2016) reported 0.14 to $0.35 \%$ mineral composition and Nwoke and Umelo (2015) 84.55 to $89.63 \mathrm{mg} / 100 \mathrm{~g}$.

The iron values ranged from 1.06 to $1.11 \mathrm{mg} / 100 \mathrm{~g}$ with the highest value recorded from Katta samples and the least from Didessa sample. No significant difference $(P>0.05)$ was observed in iron values of the two varieties. Enwere (1998) found $0.44 \mathrm{mg} / 100 \mathrm{~g}$. The high concentration of $\mathrm{Fe}$ in soymilk implies that soymilk can be used as strategic food against the 
prevalence of anemia in developing countries where resource constrained poor cannot afford to include animal products in their daily diet.

Table 2. Effects of soybean processing on mineral Composition (Cornel Method).

\begin{tabular}{|c|c|c|c|c|}
\hline \multirow[b]{2}{*}{ Variety } & \multicolumn{4}{|c|}{ Mineral composition $(\mathrm{mg} / \mathbf{1 0 0} \mathrm{g})$} \\
\hline & Phosphorous & Iron & Zinc & Calcium \\
\hline Didessa & $84.60 \pm 0.01^{\mathrm{c}}$ & $1.06 \pm 0.01^{\mathrm{c}}$ & $0.91 \pm 0.01^{\mathrm{a}}$ & $38.42 \pm 0.02^{\mathrm{a}}$ \\
\hline Katta & $85.43 \pm 0.01^{\mathrm{b}}$ & $1.11 \pm 0.01^{\mathrm{a}}$ & $0.79 \pm 0.01^{b}$ & $37.35 \pm 0.02^{\mathrm{b}}$ \\
\hline Korme & $85.82 \pm 0.02^{\mathrm{a}}$ & $1.07 \pm 0.01^{\mathrm{b}}$ & $0.71 \pm 0.01^{\mathrm{c}}$ & $36.89 \leq 0.01^{\mathrm{c}}$ \\
\hline $\mathrm{CV}$ & 0.03 & 0.69 & 2.34 & 0.09 \\
\hline LSD & 0.06 & 0.02 & 0.04 & 0.07 \\
\hline
\end{tabular}

The zinc values ranged from 0.71 to $0.91 \mathrm{mg} / 100 \mathrm{~g}$ with the highest value recorded from Didessa variety and the lowest recorded from Korme variety. Varieties significantly varied $(P<0.05)$ in Zinc content. The value of zinc content was lower than other values reported before $(0.29 \mathrm{mg} / 100 \mathrm{~g})$ (Mateos et al., 2010).

The calcium values ranged from 36.89 to $38.42 \mathrm{mg} / 100 \mathrm{~g}$ with the highest value recorded from Didessa samples $(38.42 \mathrm{mg} / 100 \mathrm{~g})$ and the lowest from Korme samples $(36.89 \mathrm{mg} / 100 \mathrm{~g})$. Differences were significant $(P<0.05)$. These values were higher than previous reports (USDA, 2005; Nezif Abachebsa et al., 2016).

\section{Illinois method}

The moisture content of soymilk of Didessa samples was 86.4, Katta 90.0, and Korme $92.2 \%$. The values were comparable to $90.5 \%$ and $92.5 \%$ for traditional and Illinois methods reported before (Wilkens et al., 1967).

The highest $(3.12 \%)$ protein content was found from Katta variety and the lowest $(2.25 \%)$ from Korme. Varieties significantly varied in protein content $(P<0.05)$. Nezif Abachebsa et al. (2016) reported 2.26 to $3.48 \%$ on their work for different variety of soymilk. On the other hand, Nwoke and Umelo (2015) found much higher protein content, i.e., 4.52 to $4.84 \%$ on their work of nutrient and sensory quality of soymilk produced from different improved varieties of soybean.

Fat content of Didessa variety was 1.58 , Katta 1.83 and Korme $1.33 \%$. Katta sample had the highest fat content $(1.83 \%)$ and Korme the lowest $(1.33 \%)$. Varieties significantly varied in fat content $(P<0.05)$. Onuorah et al. (2007) reported higher fat content $(2.3 \%)$ on their work of soymilk production by 
Illinois methods. The ash contents of soymilk ranged from 0.27 to $0.34 \%$. Didessa and Katta samples did not vary in ash content but Korme had significantly less ash content than the two. Nwoke and Umelo (2015) reported higher $(0.84$ to $0.88 \%)$ than the current one.

The fiber content of the three varieties of soymilk ranged from $0.18 \%$ from Katta to $0.25 \%$ from Didessa. Didessa and Korme varieties significantly varied in fiber content but not Katta and Korme. Nezif Abachebsa et al. (2016) reported higher fiber content (1.23 to $1.55 \%)$ on their work of soymilk production from different soybean varieties. The carbohydrate contents ranged from 3.74 to $8.65 \%$ (Table 3 ). The highest carbohydrate contents were recorded from Didessa $(8.65 \%)$ and the lowest from Korme $(3.74 \%)$. The three varieties significantly varied in carbohydrate content $(P<0.05)$. Nwoke and Umelo (2015) reported 1.66 to $2.81 \%$. Didessa variety had more energy content $(60.02 \mathrm{kcal} / 100 \mathrm{~g})$ than Korme $(35.94 \mathrm{kcal} / 100 \mathrm{~g})$. Varieties significantly varied in energy output. On the other hand, USDA nutrient database showed $446 \mathrm{kcal} / 100 \mathrm{~g}$.

Table 3. Effects of soybean processing on proximate composition of soybean variety (Illinois method).

\begin{tabular}{crrrrr}
\hline & \multicolumn{1}{c}{ Didessa } & \multicolumn{1}{c}{ Katta } & \multicolumn{1}{c}{ Korme } & \multicolumn{1}{c}{ CV } & \multicolumn{1}{c}{ LSD } \\
\hline Moisture (\%) & $86.39 \pm 0.02 \mathrm{c}$ & $90.01 \pm 0.03 \mathrm{~b}$ & $92.21 \pm 0.02 \mathrm{a}$ & 0.04 & 0.08 \\
Protein (\%) & $2.79 \pm 0.01 \mathrm{~b}$ & $3.12 \pm 0.01 \mathrm{a}$ & $2.25 \pm 0.01 \mathrm{c}$ & 0.51 & 0.03 \\
Fat (\%) & $1.58 \pm 0.02 \mathrm{~b}$ & $1.83 \pm 0.02 \mathrm{a}$ & $1.33 \pm 0.01 \mathrm{c}$ & 1.78 & 0.06 \\
Ash (\%) & $0.34 \pm 0.02 \mathrm{a}$ & $0.34 \pm 0.02 \mathrm{a}$ & $0.27 \pm 0.01 \mathrm{~b}$ & 7.11 & 0.04 \\
Fiber (\%) & $0.25 \pm 0.01 \mathrm{a}$ & $0.18 \pm 0.01 \mathrm{~b}$ & $0.19 \pm 0.01 \mathrm{~b}$ & 5.62 & 0.02 \\
Carbohydrate (\%) & $8.65 \pm 0.06 \mathrm{a}$ & $4.52 \pm 0.02 \mathrm{~b}$ & $3.74 \pm 0.02 \mathrm{c}$ & 1.25 & 0.14 \\
Inergy (kcal/100g) & $60.02 \pm 0.09 \mathrm{a}$ & $47.03 \pm 0.11 \mathrm{~b}$ & $35.94 \pm 0.16 \mathrm{c}$ & 0.45 & 0.43 \\
\hline
\end{tabular}

ere; $\mathrm{CV}=$ Coefficient of Variation and LSD $=$ Least Significant Difference

The mineral composition of soymilk from different variety of soybean is shown in (Table 4). The phosphorous content ranged from 82.35 in Korme to $84.31 \mathrm{mg} / 100 \mathrm{~g}$ in Didessa. The three varieties significantly varied in mineral composition $(P<0.05)$. Nwoke and Umelo (2015) reported slightly higher mineral content $(84.55$ to $89.63 \mathrm{mg} / 100 \mathrm{~g})$ than the current one.

Iron values ranged from $1.01 \mathrm{mg} / 100 \mathrm{~g}$ in Katta to $1.16 \mathrm{mg} / 100 \mathrm{~g}$ in Didessa, which varied significantly between varieties $(P<0.05)$. Enwere $(1998)$ found $1.44 \mathrm{mg} / 100 \mathrm{~g}$. The variation could have come from the variety of the soybean and the processing conditions. USDA (2005) reported $0.6 \mathrm{mg} / 100 \mathrm{~g}$, which was lower than the current report. 
Table 4. Effects of soybean processing on mineral composition (Illinois method).

\begin{tabular}{|c|c|c|c|c|}
\hline \multicolumn{5}{|c|}{ Mineral composition $(\mathrm{mg} / \mathbf{1 0 0} \mathrm{g})$} \\
\hline Variety & Phosphorous & Iron & Zinc & Calcium \\
\hline Didessa & $84.31 \pm 0.01^{\mathrm{a}}$ & $1.16 \pm 0.01^{\mathrm{a}}$ & $0.87 \pm 0.01^{\mathrm{a}}$ & $36.32 \pm 0.02^{\mathrm{b}}$ \\
\hline Katta & $83.52 \pm 0.02^{\mathrm{b}}$ & $1.01 \pm 0.01^{\mathrm{c}}$ & $0.86 \pm 0.02^{\mathrm{a}}$ & $37.32 \pm 0.02^{\mathrm{a}}$ \\
\hline Korme & $82.35 \pm 0.02^{\mathrm{c}}$ & $1.08 \pm 0.01^{\mathrm{b}}$ & $0.75 \pm 0.01^{\mathrm{b}}$ & $35.83 \pm 0.03^{\mathrm{c}}$ \\
\hline LSD & $\begin{array}{l}0.04 \\
0.04\end{array}$ & $\begin{array}{l}0.68 \\
0.07\end{array}$ & $\begin{array}{l}2.93 \\
0.05\end{array}$ & $\begin{array}{l}0.12 \\
0.08\end{array}$ \\
\hline
\end{tabular}

Where; $\mathrm{CV}=$ Coefficient of Variation and LSD $=$ Least Significant Difference

Zinc contents ranged from 0.75 to $0.87 \mathrm{mg} / 100 \mathrm{~g}$, with the lowest $(0.87$ $\mathrm{mg} / 100 \mathrm{~g})$ from Didessa and the highest $(0.75 \mathrm{mg} / 100 \mathrm{~g})$ from Korme. Korme and Katta and Korme and Didessa varied significantly in zinc content but not Didessa and Katta. United Soybean Board (USDA, 2005) reported 0.54 $\mathrm{mg} / 100 \mathrm{~g}$. Nezif Abachebsa et al. (2016) reported $0.343 \mathrm{mg} / 100 \mathrm{~g}$ for Clark $63 \mathrm{~K}$ variety and $0.433 \mathrm{mg} / 100 \mathrm{~g}$ Awasa 95 variety by using Illinois processing methods.

Varieties varied significantly in calcium content, which ranged from 35.83 $\mathrm{mg} / 100 \mathrm{~g}$ in Korme to $37.32 \mathrm{mg} / 100 \mathrm{~g}$ in Katta. While USDA (2005) reported lower calcium content than the current one, Udeozor (2012) reported higher, i.e., $44.5 \mathrm{mg} / 100 \mathrm{~g}$. Nezif Abachebsa et al. (2016) found very much less calcium, i.e., 0.03 to $0.043 \mathrm{mg} / 100 \mathrm{~g}$ than the current finding.

\section{Traditional methods}

The highest moisture content was recorded from Korme $(90.33 \%)$ and the lowest from Didessa (87.45\%). Similar findings were reported on traditional processing of soymilk by Onuorah et.al. (2007) in which they found a value of $87.0 \%$.

The highest protein content $(2.23 \%)$ was recorded from Katta and the lowest from Korme $(1.80 \%)$. Katta and Didessa varied in protein content but not Didessa and Katta. Nwoke and Umelo (2015) reported higher protein content (4.52 to $4.84 \%$ ) than the current one. The fat contents ranged from $1.11 \%$ in Katta to $1.34 \%$ in Didessa. Fat content varied between Didessa and Katta and also Katta and Korme but not between Didessa and Korme. These findings were in line with the work of Nezif Abachebsa et al. (2016) in which they reported the value of 1.4 to $1.8 \%$ for different processing methods. 
The highest ash contents were recorded from Didessa (1.17\%) and the lowest from Katta (1.14\%). Didessa and Katta and also Didessa and Korme varied in ash content.

These findings were higher than the value ( 0.4 to $0.45 \%)$ reported by Onuorah et al. (2007) on their work of comparative physicochemical evaluation of soymilk and soycake produced by three different methods. The fiber ranged from 0.13 to $0.18 \%$. The fiber content recorded was higher as compared to previous reports, but also was lower than the value reported by Nezif Abachebsa et al. (2016). This could be due to the soybean variety, growing conditions and processing methods employed to produce soymilk.

Table 5. Effects of soybean processing on proximate composition using Traditional methods.

\begin{tabular}{crrrrr}
\hline & \multicolumn{1}{c}{ Didessa } & \multicolumn{1}{c}{ Katta } & \multicolumn{1}{c}{ Korme } & \multicolumn{1}{c}{ CV } & \multicolumn{2}{c}{ LSD } \\
\hline Moisture (\%) & $87.45 \pm 0.04^{\mathrm{c}}$ & $89.49 \pm 0.02^{\mathrm{b}}$ & $90.33 \pm 0.02^{\mathrm{a}}$ & 0.07 & 0.12 \\
Protein (\%) & $2.13 \pm 0.01^{\mathrm{a}}$ & $2.23 \pm 0.08^{\mathrm{a}}$ & $1.80 \pm 0.01^{\mathrm{b}}$ & 4.34 & 0.18 \\
Fat (\%) & $1.34 \pm 0.02^{\mathrm{a}}$ & $1.11 \pm 0.01^{\mathrm{b}}$ & $1.29 \pm 0.01^{\mathrm{a}}$ & 1.91 & 0.05 \\
Ash (\%) & $0.17 \pm 0.01^{\mathrm{a}}$ & $0.14 \pm 0.01^{\mathrm{b}}$ & $0.15 \pm 0.01^{\mathrm{b}}$ & 4.86 & 0.02 \\
Fiber (\%) & $0.13 \pm 0.01 \mathrm{~b}$ & $0.18 \pm 0.01 \mathrm{a}$ & $0.13 \pm 0.01 \mathrm{~b}$ & 8.73 & 0.03 \\
2arbohydrate (\%) & $8.77 \pm 0.07^{\mathrm{a}}$ & $6.86 \pm 0.09^{\mathrm{b}}$ & $6.28 \pm 0.02^{\mathrm{c}}$ & 1.64 & 0.24 \\
nergy (kcal/100 g) & $55.64 \pm 0.20^{\mathrm{a}}$ & $46.33 \pm 0.12^{\mathrm{b}}$ & $44.02 \pm 0.13^{\mathrm{c}}$ & 0.56 & 0.55 \\
\hline
\end{tabular}

ere CV $=$ Coefficient of Variation and LSD $=$ Least Significant Difference.

The highest carbohydrate was recorded from Didessa $(8.77 \%)$ and lowest from Korme (6.28\%). Varieties significantly varied in carbohydrate content. For example, Nazif Abachebsa et al. (2016) reported lower than the current 1.63 to $5.28 \%$.

The highest $(55.64 \mathrm{kcal} / 100 \mathrm{~g})$ energy content was recorded from Didessa variety and the lowest $(44.02 \mathrm{kcal} / 100 \mathrm{~g})$ from Korme. All varieties varied in energy content. This finding was lower than the value of $446 \mathrm{kcal} / 100 \mathrm{~g}$ reported by USDA nutrient database.

The phosphorous content ranged from 77.64 to $78.22 \mathrm{mg} / 100 \mathrm{~g}$. The highest value was recorded from Didessa and the lowest from Korme. Varieties varied significantly in phosphorus content. The phosphorous content of soymilk was higher $(78.99 \mathrm{mg} / 100 \mathrm{~g})$ as compared to the values of $52 \mathrm{mg} / 100 \mathrm{~g}$ reported by USDA (2005). But it was lower than the value ( 84.55 to $89.63 \mathrm{mg} / 100 \mathrm{~g}$ ) reported by Nwoke and Umelo (2015) in which they conducted on nutrient and sensory quality of soymilk produced from different improved varieties of soybean. 
Table 6. Mineral contents of soybean processing by Traditional methods.

\begin{tabular}{|c|c|c|c|c|}
\hline \multicolumn{5}{|c|}{ neral composition $(\mathrm{mg} / 100 \mathrm{~g})$} \\
\hline Sample code & osphorous & n & lc & lcium \\
\hline Didessa & $22 \pm 0.02 b$ & $7 \pm 0.01 \mathrm{a}$ & $1 \pm 0.01 \mathrm{a}$ & $31 \pm 0.01 \mathrm{a}$ \\
\hline Katta & $99 \pm 0.05 \mathrm{a}$ & $8 \pm 0.01 b$ & $4 \pm 0.01 \mathrm{~b}$ & $23 \pm 0.01 b$ \\
\hline Korme & $54 \pm 0.02 c$ & $1 \pm 0.01 b$ & $3 \pm 0.01 \mathrm{a}$ & $32 \pm 0.02 \mathrm{c}$ \\
\hline $\mathrm{CV}$ & 7 & J & 6 & 8 \\
\hline LSD & 1 & 3 & 4 & 5 \\
\hline
\end{tabular}

Where; $\mathrm{CV}=$ Coefficient of Variation and LSD = Least Significant Difference

The iron values ranged from 0.78 to $0.87 \mathrm{mg} / 100 \mathrm{~g}$ with the highest from Didessa and the lowest from Katta. Didessa and Katta and also Didessa and Korme varied in iron content, but not Katta and Korme. USDA (2005) reported $0.6 \mathrm{mg} / 100 \mathrm{~g}$, which was lower than the current one. But it was lower than the value of Nwoke and Umelo (2015).

The content of zinc ranged from 0.54 to $0.63 \mathrm{mg} / 100 \mathrm{~g}$ with highest from Korme and the lowest from Katta variety. Varieties Didessa and Katta varied but not Didessa and Korme. Nezif Abachebsa et al. (2016) reported similar values ( 0.343 to $0.70 \mathrm{mg} / 100 \mathrm{~g})$.

The calcium value ranged from 33.82 to $34.31 \mathrm{mg} / 100 \mathrm{~g}$ with the highest from Didessa and the lowest from Korme. Varieties significantly varied in calcium content. Udeozer (2012) reported similar calcium contents of unfortified soymilk. Nezif Abachebsa et al. (2016) reported extremely low contents of calcium, i.e., 0.033 to $0.036 \mathrm{mg} / 100 \mathrm{~g}$, compared to the current study.

\section{CONCLUSION}

The nutritional composition of improved Didessa soybean variety gave better nutritional composition as compared to the improved Katta and Korme by Cornel processing methods. Illinois processing methods also gave better nutritional composition for Didessa soybean variety as compared to Korme and Katta with the same processing methods. Traditional processing methods gave better nutritional composition for Didessa soybean variety. The mineral contents of improved soybean variety of Didessa gave better phosphorous and calcium by Corner processing method as compared to the other processing methods and improved varieties. Cornel and Illinois processing methods for improved variety of Didessa, Katta and Korme gave better nutritional composition and mineral contents as compared to traditional processing 
methods. Generally, among the three methods of soybean processing, Cornel gave better nutritional composition and mineral contents compared to the other two. Improved Didessa variety contained better nutritional composition and mineral contents compared to improved Korme and Katta soybean varieties. Therefore, Cornel processing methods for soymilk extraction was the best method and Didessa variety contained better nutritional composition.

\section{CONFLICT OF INTEREST}

The author declares that there is no conflict of interest

\section{ACKNOWLEDGEMENTS}

The author thanks Wollega University for financing the research, Department of Food Science and Postharvest Technology (Jimma University) for facilitating the laboratory activities.

\section{REFERENCES}

AACC (2000). Method 40-56.01: Phosphorus gravimetric method. American Association of Cereal Chemist Inc., St. Paul, MN.

Adebayo-Tayo, B.C., Adegoke, A.A and Akinjogunla, O.J. (2009). Microbial and physico-chemical quality of powdered soymilk samples in Akwa Ibom, SouthSouthern Nigeria. African Journal of Biotechnology 8: 3066-3071.

Afroz, M.F., Anjum, W., Islam, N., Kobir, A., Hossain, K and Sayed, A. (2016). Preparation of soymilk using different methods. Journal of Food and Nutrition Sciences 4(1): 11-17.

Aidoo, H., Sakyi-Dawson, E., Tano-Debrah, K and Saalia, F.K. (2010). Development and characterization of dehydrated peanut-cowpea milk powder for use as a dairy milk substitute in chocolate manufacture. Food Research International 43: 79-85.

AOAC (2000). Official methods of analysis, 18th Ed. AOAC International, Gaithersburg, MD.

Bansal, R and Kaur, M. (2014). Quality improvement and sensory evaluation of soya milk prepared by germinated soybeans. International Journal of Food and Nutrition Sciences 3: 136-144.

Babajide, A.A. (1985). Production of "SoyWarankasi", effect of calcium treatment and $\mathrm{pH}$ adjustment on yield and quality. Unpublished M.Sc. Thesis, University of Ibadan, Ibadan, Nigeria.

EARO (Ethiopian Agricultural Research Organization) (2001). Crop protection research program strategy, Addis Ababa, Ethiopia.

Eskedar Kifle (2012). Faffa unveils new product. Retrieved from http://www.capitalethiopia.com/index.php (accessed March 20, 2015).

Enwere, N.J. (1998). Food of plant origin-Afro-Orbis. Pub. Ltd. Nsukka Nig. 
Fafaungwithayakul, N., Hongsprabhas, P and Hongsprabhas, P. (2011). Effect of soy soluble polysaccharide on the stability of soy-stabilised emulsions during in vitro protein digestion. Food Biophysics 6(3): 407-415.

Hsieh, C and Yang, F.C. (2004). Reusing soy residue for the solid-state fermentation of Ganoderma lucidum. Bioresource Technology 91(1): 105-109.

Johnson, W.K and Snyder, H.E. (1978). Soy milk, comparison of processing method. Yield and composition. Journal of Food Science 43: 349.

Kale, R.V., Pandhare, G.R., Satwase, A.N and Goswami, D. (2012). Effect of different concentration of orange juice on quality characteristics of soya milk blended beverage. Journal of Food Processing and Technology 3(2): 1-5.

Khatib, K.A., Aramouni, F.M., Herald, T.J and Boyer, J.E. (2002). Physicochemical characteristics of soft tofu formulated from selected soybean varieties. Journal of Food Quality 25: 289-303.

Khode, S.U., Shinde, K.S and Yenge, G.B. (2015). A study on the storage of sterilized soymilk. International Journal of Farm Science 4: 166-179.

Kirk, R.S and Sawer, R. (1991). Pearson's composition and analysis of foods. $9^{\text {th }}$ edn., pp. 32-33, Longman Scientific and Technology, Harlow, Essex.

Lozano, P.R., Drake, M., Benitez, D and Cadwallader, K.R. (2007). Instrumental and sensory characterization of heat-induced odorants in aseptically packaged soymilk. Journal of Agriculture and Food Chemistry 55: 3018-3026.

Mateos-Aparicio, I., Redondo-Cuenca, A and Villanueva-Su'arez, M.J. (2010). Isolation and characterization of cell wall polysaccharides from legume byproducts: Okara (soymilk residue), pea pod and broad bean pod. Food Chemistry 122(1): 339-345.

MoARD (Ministry of Agriculture and Rural Development) (2009). Animal and plant health regulatory directorate. Crop variety register, issue No. 12, pp. 88-89, Ministry of Agriculture and Rural Development, Addis Ababa, Ethiopia.

Murtaza, A and Shahid, S.H. (2007). Physico-chemical and sensory evaluation of ready to drink soy-cow milk blend. Pakistan Journal of Nutrition 6: 283-285.

Muroyama, K., Atsumi, R and Andoh, A. (2006). Effect of pretreatment on lactic acid fermentation of bean curd refuse with simultaneous saccharification. Studies in Surface Science and Catalysis 159: 133-136.

Nezif Abachebsa, Ali Mohammed, Tilahun Abera, Techale Birhan (2016). Effects of soybean varieties and processing methods on nutritional and sensory properties of soymilk. Journal of Food Processing and Preservation 41(4).

Obadina, A.O., Akinola, O.J., Shittu, T.A and Bakare, H.A. (2013). Effect of natural fermentation on the chemical and nutritional composition of fermented soymilk Nono. Nigerian International Food Journal 31: 91-97.

Odu, N.N., Egbo, N.N and Okonko, I.O. (2012). Assessment of the effect of different preservatives on the shelf-life of soymilk stored at different temperatures. Researcher 4: 62-69.

Onuorah, C.E., Adejare, A.O and Uhiara, N.S. (2007). Comparative physicochemical evaluation of soymilk and soya cake produced by three different methods. Nigerian Food Journal 25(2). 
Rehman, S.-UR., Nawaz, H., Ahamd, M.M., Hussain, S., Murtaza, A and Shahid, S.H. (2007). Physicochemical and sensory evaluation of ready to drink soy-cow milk blend. Pakistan Journal of Nutrition 6: 283-285.

Shurtleff, W and Aoyangi, A. (2009). History of soybeans and soy foods in Africa (1857-2009), Soy Info Center, Lafayette, CA.

Suruga, K., Kato, A and Kadokura, K. (2007). 'Okara' a new preparation of food material with antioxidant activity and dietary fiber from soybean. Soybean and Nutrition 16: 311-326.

Tunde-Akintunde, T.Y and Akintunde, B.O. (2002). Development of models for predicting the yield and quality of soymilk. Journal of Food Technology 7: 55-58.

Tunde-Akintunde, T.Y and Souley, A. (2009). Effects of processing methods on quality of soymilk. Pakistan Journal of Nutrition 8: 1156-1158.

Udeozor, L.O. (2012). Tigernut-soy milk drink: Preparation, proximate composition and sensory qualities. International Journal of Food and Nutrition Science 1(4): $18-26$.

Ugochi, N.F and Chunkwuma, U.M. (2015). Nutrient and sensory quality of soymilk produced from different improved varieties of soybean. Pakistan Journal of Nutrition 14: 898-906.

Bekabil, U.T. (2015). Empirical review of production, productivity and marketability of soya bean in Ethiopia. International Journal of u-and e-Service, Science and Technology 8(1): 61-66.

USDA (2005). National nutrient database for standard reference. http://ndb.usda.gov/nd/research

Van der Riet, W.B., Wight, A.W., Cilliers, J.J.L and Datel, J.M. (1989). Food chemical investigation of tofu and its byproduct okara. Food Chemistry 34(3): 193-202.

Wangcharoen, W. (2008). Nutrition data and antioxidant capacity of soy milk ice cream and black sesame flavored soy milk ice cream. Asian Journal of Food Agroindustry 1: 205-212.

Wilkens, W.F., Mattick, L.R and Hand, D.B. (1967). Effect of processing method on oxidative off-flavour of soymilk. Food Technology 21: 1630-1633.

$\mathrm{Xu}, \mathrm{B}$ and Chang, S.K.C. (2009). Isoflavones, flavan-3-ols, phenolic acids, total phenolic profiles, and antioxidant capacities of soy milk as affected by ultra-high temperature and traditional processing methods. Journal of Agricultural and Food Chemistry 57: 4706-4717. 